International Journal of Mechanical Engineering and Technology (IJMET)

Volume 11, Issue 12, December 2020, pp. 1-11, Article ID: IJMET_11_12_001

Available online at https://iaeme.com/Home/issue/IJMET?Volume $=11 \&$ Issue $=12$

ISSN Print: 0976-6340 and ISSN Online: 0976-6359

DOI: https://doi.org/10.34218/IJMET.11.12.2020.001

(C) IAEME Publication

Scope Database Indexed

\title{
ERP SYSTEM SELECTION FOR SMALL MEDIUM ENTERPRISES (SMES): A SYSTEMATIC LITERATURE REVIEW
}

\author{
Naaman Yulianto \\ Binus Graduate Program, BINUS Graduate School - Doctor of Computer Science \\ Bina Nusantara University Jakarta, Indonesia
}

\author{
Meyliana \\ Information System Department, School of Information System \\ Bina Nusantara University, Jakarta, Indonesia \\ Harjanto Prabowo \\ Computer Science Department \\ BINUS Graduate School - Doctor of Computer Science \\ Bina Nusantara University, Jakarta, Indonesia \\ Ahmad Nizar Hidayanto \\ Faculty of Computer Science Universitas Indonesia \\ Depok, Indonesia
}

\begin{abstract}
ERP is a software that functions to manage and integrate various operational activities in a business. With the development of cloud computing, ERP has become affordable software for SMEs. Currently there are so many ERP products on the market, where most SMEs do not have IT resources who understand how to choose the appropriate ERP product. One of the success of ERP implementation is determined in the product selection phase, therefore it is very important to know what factors must be considered when choosing an ERP product. In this paper, we follow the Systematic Literature Review (SLR) research method, reviewed 51 articles, to explore criteria of selection ERP in SMEs. This paper classifies the ERP selection factors into five factors and is grouped between developed and developing countries. ERP selection factors for developed and developing countries are quite different. But in general, the most important factor to be considered is business functionality.
\end{abstract}

Key words: ERP, SME, Selection, Enterprise Resource Planning, Small Medium Enterprises 
Cite this Article: Naaman Yulianto, Meyliana, Harjanto Prabowo and Ahmad Nizar Hidayanto, ERP System Selection for Small Medium Enterprises (SMEs): A Systematic Literature Review, International Journal of Mechanical Engineering and Technology. 11(12), 2020, pp. 1-11.

https://iaeme.com/Home/issue/IJMET?Volume=11\&Issue $=12$

\section{INTRODUCTION}

Enterprise resource planning (ERP) refers to a type of software that organizations use to manage day-to-day business activities such as accounting, procurement, project management, risk management and compliance, and supply chain operations. A complete ERP suite also includes enterprise performance management, software that helps plan, budget, predict, and report on an organization's financial results.

ERP systems tie together a multitude of business processes and enable the flow of data between them. By collecting an organization's shared transactional data from multiple sources, ERP systems eliminate data duplication and provide data integrity with a single source of truth.

ERP adoption cycle consist three phases: selection, implementation and use. The selection phase is the most important for successful adoption [4].

Currently there are so many ERP products on the market, with a variety of different technology and platform, companies, specially SMEs and Start-up company are confused about what ERP product they should use and don't know how to evaluate ERP product selection. Basically, there are two kinds of ERP softwares, Proprietary Software (PS) ERP and Open Source Software (OSS) ERP [45].

Over the last decade, implementation of ERP in SMEs is becoming common, as the technology is more established and prices come down. Some of ERP vendors now focus primarily on SMEs, and also by nothing that many large ERP vendors such as SAP, Oracle, Microsoft, are actively expanding their business activities to the SME sector [2]. SAP has SAP Business One, Oracle has Netsuite, Microsoft has Navision. There are several other products, such as Odoo, Sage Intacct, Acumatica, Epicor.

However, there is no system that is best for all business process, but rather there is a process we can go through to find the right system. The step that is missed most often is defining the reason for selecting the system [14].

This paper will review previous studies to answer the following research question: what are the factors need to be consider in choosing an ERP system for SMEs?

\section{THEORITICAL FOUNDATIONS}

\subsection{Enterprise Resource Planning}

An ERP system is an enterprise packaged software system that helps an organization to manage and effectively use of its resources by providing an integrated solution for its informationprocessing needs [37].

A common platform to integrate the industry multi models and application software to enhance the business function is ERP [46].

Cloud ERP enables SME to compete with larger corporations through implementing an inexpensive, advanced ERP system [5].

Success or failure in ERP implementation is very difficult to measure, because it involves multi-dimensional factors. Sometimes many problems occur in the early phase, but cannot be detected [24]. 


\subsection{Small Medium Enterprises}

This paper discussed the selection of ERP for SMEs in various countries. Each country has a different definition of SME.

In Indonesia, medium enterprise has turnover between 250,000 USD to 5,000,000 USD per year, and having full employee between 20-99 [42]. In Malaysia, medium enterprise has turnover between 10,000,000 RM and 25,000,000 RM, and having full time employees between 51-150 [40]. In Thailand, medium enterprise has turnover between 50,000,000 THB to 200,000,000 THB per year, and having full employee between 51-200 [44].

Economic growth in some of Asia countries like Japan, Korea and China has been influenced by the SMEs activities where their Gross Domestic Product (GDP) had reached more than 50\% [40]. In India, the growth in SMEs also shown contribution towards GDP is $17 \%$ [11]. In India, SMEs are defined as those having capital investments in the range of 25 lakh-10 crore INR for manufacturing sector and 10 lakh-5 crore INR for service sector [36]. SMEs represent a significant sector of the Singapore economy, they have employed more than $80 \%$ workforce in Singapore [48].

The economies of Denmark, Portugal, Spain, and Sweden are greatly composed of SMEs [34]. In Europe, medium enterprise has turnover between 7,000,000 EUR to 40,000,000 EUR per year, and having full employee between 51-250 [10].

UK economy is driven mostly by a large number of SMEs [23]. In UK, SMEs turnover is approximately $£ 7.5-10$ million per year [16].

\section{METHODOLOGY}

The research methodology used in this study is the review of literature on ERP for SME. The focus of the literature review was on articles published between 2000 and 2020. Writing this document involves several steps: determining the database used, determining the keywords to be used, determining the criteria for inclusion and exclusion, extracting data and analyzing the found literature.

\subsection{Search Process}

The first step is determining the database used. In this review process, there are five (5) database source selected, as follow:

- IEEE Xplore Digital Library (https:// ieeexplore. ieee. Org / Xplore/home.jsp)

- Wiley Online Library (https://onlinelibrary.wiley.com/)

- Science Direct (https://www.sciencedirect.com/ )

- Emerald Insight (https://www.emeraldinsight.com/)

- Springer Link (https://link.springer.com/)

After selecting the source database, search keyword were determined. Filtering done by combining the Boolean operators. The combination of the keywords are follows:

- (('ERP' AND 'Selection' AND 'SME') OR ('Enterprise Resource Planning' AND 'Selection' AND 'SME'))

- (('Enterprise Resource Planning' AND 'Selection' AND 'Small Medium Enterprise') OR ('Enterprise Resource Planning' AND 'Selection' AND 'Small Medium Enterprise')). 


\subsection{Inclusion and Exlusion Crtiteria}

After entering the keyword in the source database, by reading the article title, the total summary of the article is displayed as 'studied found'. After reading the abstract, if the abstract is related to the research questions, the article will be presented as 'candidate studies'. All 'candidate studies' articles result will be read thoroughly to search for answer to the research questions, if appropriate it will be displayed as 'selected studies'.

\subsection{Data Extraction}

In the initial phase, 226 papers were found that were relevant to research question to be answered. After reviewing abstract from the papers, there were 111 papers included in the Candidates studies. However, after being studied further, there are only 51 papers which can be included in this research's basis.

Table 1 Data Extraction in Inclusion Criteria

\begin{tabular}{|c|c|c|c|}
\hline Selected Studies & $\begin{array}{c}\text { Studies } \\
\text { found }\end{array}$ & $\begin{array}{c}\text { Candidate } \\
\text { studies }\end{array}$ & $\begin{array}{c}\text { Selected } \\
\text { studies }\end{array}$ \\
\hline IEEE Xplore Digital Library & 70 & 35 & 19 \\
\hline Wiley Online Library & 25 & 8 & 5 \\
\hline Science Direct & 17 & 11 & 8 \\
\hline Emerald Insight & 41 & 30 & 12 \\
\hline Springer Link & 68 & 24 & 5 \\
\hline Other & 5 & 3 & 2 \\
\hline Total & 226 & 111 & 51 \\
\hline
\end{tabular}

\section{RESULTS AND DISCUSSIONS}

After reading the 51 articles, the authors classified the demographics of the articles by country and classified the selection factors into five criteria.

\subsection{Researched Country}

This review literature includes articles from various countries, with most of them coming from India (\#8). Then the list is followed by the United Kingdom, Indonesia, Australia, Korea, Malaysia, Norway and Turkey. Based on table 6, more articles are written in developed countries (\#34) than in developing countries (\#17).

Selected studied articles were published from 26 countries, 44 institutions and 45 authors.

Table 2 Researched Country

\begin{tabular}{|c|c|c|c|c|c|}
\hline Country & Articles & \# inst. & \% inst. & \# authors & \% authors \\
\hline Australia & {$[31[38]$} & 2 & $4.55 \%$ & 2 & $4.44 \%$ \\
\hline Belgium & {$[12]$} & 1 & $2.27 \%$ & 1 & $2.22 \%$ \\
\hline Canada & {$[30]$} & 1 & $2.27 \%$ & 1 & $2.22 \%$ \\
\hline China & {$[27]$} & 1 & $2.27 \%$ & 1 & $2.22 \%$ \\
\hline Finland & {$[21]$} & 1 & $2.27 \%$ & 1 & $2.22 \%$ \\
\hline France & {$[13]$} & 1 & $2.27 \%$ & 1 & $2.22 \%$ \\
\hline Greece & {$[29]$} & 1 & $2.27 \%$ & 1 & $2.22 \%$ \\
\hline Hungary & {$[51]$} & 1 & $2.27 \%$ & 1 & $2.22 \%$ \\
\hline India & {$[8][9][11][17][22]$} & 8 & $18.18 \%$ & 8 & $17.78 \%$ \\
\hline Indonesia & {$[35][36][37]$} & & & & \\
\hline
\end{tabular}


Naaman Yulianto, Meyliana, Harjanto Prabowo and Ahmad Nizar Hidayanto

\begin{tabular}{|c|c|c|c|c|c|}
\hline Country & Articles & \# inst. & \% inst. & \# authors & $\%$ authors \\
\hline Iran & [50] & 1 & $2.27 \%$ & 1 & $2.22 \%$ \\
\hline Italy & [10] & 1 & $2.27 \%$ & 1 & $2.22 \%$ \\
\hline Jordan & [6] & 1 & $2.27 \%$ & 1 & $2.22 \%$ \\
\hline Korea & [3] [14] & 2 & $4.55 \%$ & 2 & $4.44 \%$ \\
\hline Malaysia & [7] [39] [40] & 2 & $4.55 \%$ & 2 & $4.44 \%$ \\
\hline Morocco & [1] & 1 & $2.27 \%$ & 1 & $2.22 \%$ \\
\hline Netherlands & [47] & 1 & $2.27 \%$ & 1 & $2.22 \%$ \\
\hline Norway & [15] [49] & 2 & $4.55 \%$ & 2 & $4.44 \%$ \\
\hline Portugal & [32] [33] [34] & 1 & $2.27 \%$ & 1 & $2.22 \%$ \\
\hline Singapore & [48] & 1 & $2.27 \%$ & 1 & $2.22 \%$ \\
\hline Sweden & [18] & 1 & $2.27 \%$ & 1 & $2.22 \%$ \\
\hline Thailand & [44] & 1 & $2.27 \%$ & 1 & $2.22 \%$ \\
\hline Turkey & [19] [20] & 2 & $4.55 \%$ & 2 & $4.44 \%$ \\
\hline UAE & {$[5]$} & 1 & $2.27 \%$ & 1 & $2.22 \%$ \\
\hline UK & {$[2][4][16][23][25]$} & 5 & $11.36 \%$ & 6 & $13.33 \%$ \\
\hline USA & {$[24]$} & 1 & $2.27 \%$ & 1 & $2.22 \%$ \\
\hline \multicolumn{2}{|c|}{ Total country: 26 countries } & 44 & & 45 & \\
\hline
\end{tabular}

\subsection{Selection Factors}

Based on the literature studied, the authors classified the ERP selection factors into five major criteria.

\section{Business Functionality}

Although many ERP systems claim to cover end to end processes, sometimes there are some business processes that cannot be covered. The fitness of the desired business process requirements with ERP functionality is one of the important criteria that needs to be considered. Business functionality sub-criteria usually covers business functions such as finance, supply chain, manufacturing, sales, service, procurement, marketing. One important thing to note here is that the system must be aligned with the business processes and the ERP that is closest to the requirement should only be used [37]. Degree of the ERP system compatibility towards the organization business processes and procedure [39].

\section{Supporting Service}

Supporting service sub-criteria usually include the going concern of the ERP system, supporting the principal and vendor implementers to carry out maintenance and upgrades, availability of training courses and documentation [3].

\section{Technology}

Technology sub-criteria include ease of use, easy to implement, easy to extend or integrate, has compliance security. Legacy system could not communicate with one another system [30]. Determining the technology chosen is also closely related to the total project cost. Overall ERP architecture should be established well before the deployment [37].

\section{Total Cost}

Total cost sub-criteria include product license costs, implementation costs and maintenance costs. With a Cloud based ERP solution, it is possible for cloud ERP vendors to provide services in a cost effective manner [13]. Most organizations often fail to calculate hidden costs during evaluation, implementation, and post implementation support [17]. 


\section{Vendor Credentials}

Vendor credentials sub-criteria include vendor experience and consultant experience they have, implementation strategies. If the ERP package is implemented by professionals who do not have adequate knowledge about the business, it leads to improper mapping of the business processes [17]. Many ERP vendors that were successful in one technology simply have not been successful in the move to the next [14]. Trust on vendor facilitates enough room for the company to implement any new changes in their business process [22].

Table 3 Selection Factors

\begin{tabular}{|c|c|c|c|c|}
\hline Selection Factors & Articles & \# & $\begin{array}{l}\text { Developed } \\
\text { Country }\end{array}$ & $\begin{array}{l}\text { Developing } \\
\text { Country }\end{array}$ \\
\hline $\begin{array}{c}\text { Business } \\
\text { Functionality }\end{array}$ & $\begin{array}{c}{[2][3][4][7][10][12][13][14]} \\
{[16][17][18][19][20][21][22]} \\
{[23][24][26][27][28][29][31]} \\
{[32][33][34][37][39][40][41]} \\
{[42][44][45][46][47][48][49]} \\
{[50][51]}\end{array}$ & 38 & 27 & 11 \\
\hline $\begin{array}{l}\text { Supporting } \\
\text { Services }\end{array}$ & $\begin{array}{c}{[3][7][15][17][23][24][27][29]} \\
{[38][44][46][50]}\end{array}$ & 12 & 8 & 4 \\
\hline Technology & $\begin{array}{l}11][2][3][4][5][6][7][8][10] \\
{[12][13][14][16][17][18][19]} \\
{[20][23][25][26][27][28][29]} \\
{[30][32][33][34][36][37][38]} \\
{[39][43][44][46][48][49][50]}\end{array}$ & 37 & 27 & 10 \\
\hline Total Cost & \begin{tabular}{|c|}
$3][8][11][12][13][17][18][20]$ \\
{$[21][22][26][27][31][35][36]$} \\
{$[37][38][40][44][46][50][51]$}
\end{tabular} & 22 & 11 & 11 \\
\hline $\begin{array}{l}\text { Vendor } \\
\text { Credentials }\end{array}$ & $\begin{array}{c}{[1][2][3][4][5][9][13][14][15]} \\
{[16][17][22][23][29][36][37]} \\
{[38][43][44][50][51]}\end{array}$ & 21 & 13 & 8 \\
\hline
\end{tabular}

Based on the data presented in table 3, business functionality is the most widely discussed factor in the literature studied (\#38), followed by factors such as technology (\#37), total cost (\#22), vendor credential (\#21) and supporting services (\#12).

In developed countries, the most determining factors are business functionality (\#27) and technology (\#27), followed by credential vendor (\#13), total cost (\#11) and supporting service (\#8). Articles that discuss technology usually also discuss business functionality, therefore it can be concluded that the choice of technology is closely related to the available business functionality.

In developing countries, the most determining factor are business functionality (\#11) and total cost (\#11), followed by technology (\#10), business functionality (\#9), vendor credentials (\#8) and supporting services (\#4).

Business functionality ranks most important in both developed and developing countries. However, in developed countries, the technology factor is also an important consideration. Meanwhile, in developing countries, the total cost factor is also an important consideration. 


\section{CONCLUSION}

In developed countries the determining factor is business functionality and technology, while in developing countries the determining factor is business functionality and total cost.

The difference of turnover between developed and developing countries is quite significant, so the total cost factor is important for SMEs in developing countries, rather than SMEs in developed countries.

In general, the most important thing in choosing an ERP system is that the ERP system must have business functionality that matches the company's business processes. This applies equally to both developed and developing countries

The factor that is most often overlooked is the supporting services factor, this applies equally to both developed and developing countries. Even though that factor is also quite important for the continuity of the ERP system after the implementation phase.

\subsection{Theoretical Implication}

ERP is an application that can integrate a company's business functions, so that ERP business functionality is an important factor in ERP selection. ERP business functionality must be able to map to company business processes.

\subsection{Practical Implication}

The selection process should not be overlooked in choosing an ERP product, so that the success of ERP implementation can be ensured. Choosing the right ERP product is expected to provide accurate real information, so that information can be used to make decisions and provide added value to the company. Meanwhile, the wrong choice of ERP products can result in burdens for the company.

\subsection{Limitation and Future Research}

This paper has not yet analyzed the framework used in each studied articles. The selected studied articles only discusses the selection of ERP for SMEs, for future research, it can be more specific for start-up companies that already have an injection of funds, where start-up companies usually already have a front end application that is already running to support their business, before they implement ERP as a back end application. For this reason, it is necessary to examine whether business functionality and technology are the most important factor in choosing an ERP system, especially for start-up companies.

\section{REFERENCES}

[1] A. A. Achargui and A. Zaouia, "Hosted, cloud and SaaS, off-premises ERP systems adoption by Moroccan SMEs: A focus group study," 2016 7th Int. Conf. Sci. Electron. Technol. Inf. Telecommun. SETIT 2016, pp. 344-348, 2017, doi: .1109/SETIT.2016.7939891.

[2] M. M. Ahmad and R. P. Cuenca, "Critical success factors for ERP implementation in SMEs," Robot. Comput. Integr. Manuf., vol. 29, no. 3, pp. 104-111, 2013, doi: 10.1016/j.rcim.2012.04.019.

[3] B. S. Ahn and S. H. Choi, "ERP system selection using a simulation-based AHP approach: A case of Korean homeshopping company," J. Oper. Res. Soc., vol. 59, no. 3, pp. 322-330, 2008, doi: 10.1057/palgrave.jors.2602365. 
[4] O. Alaskari, R. Pinedo-Cuenca, and M. M. Ahmad, "Framework for selection of ERP system: Case study," Procedia Manuf., vol. 38, no. Faim 2019, pp. 69-75, 2019, doi: 10.1016/j.promfg.2020.01.009.

[5] N. M. Alsharari, M. Al-Shboul, and S. Alteneiji, "Implementation of cloud ERP in the SME: evidence from UAE," J. Small Bus. Enterp. Dev., vol. 27, no. 2, pp. 299-327, 2020, doi: 10.1108/JSBED-01-2019-0007.

[6] M. A. AL-Shboul, "Towards better understanding of determinants logistical factors in SMEs for cloud ERP adoption in developing economies," Bus. Process Manag. J., vol. 25, no. 5, pp. 887-907, 2019, doi: 10.1108/BPMJ-01-2018-0004.

[7] Z. Baharum, M. S. Ngadiman, and H. Haron, "Critical factors to ensure the successful of OS-ERP implementation based on technical requirement point of view," Proc. - 2009 3rd Asia Int. Conf. Model. Simulation, AMS 2009, pp. 419-424, 2009, doi: 10.1109/AMS.2009.96.

[8] S. Bajaj and S. Ojha, "Comparative analysis of open source ERP softwares for small and medium enterprises," Proc. 10th INDIACom; 2016 3rd Int. Conf. Comput. Sustain. Glob. Dev. INDIACom 2016, pp. 1047-1050, 2016.

[9] V. Bansal and A. Agarwal, "Enterprise resource planning: identifying relationships among critical success factors," Bus. Process Manag. J., vol. 21, no. 6, pp. 1337-1352, 2015, doi: 10.1108/BPMJ-12-2014-0128.

[10] G. Buonanno, P. Faverio, F. Pigni, A. Ravarini, D. Sciuto, and M. Tagliavini, "Factors affecting ERP system adoption: A comparative analysis between SMEs and large companies," J. Enterp. Inf. Manag., vol. 18, no. 4, pp. 384-426, 2005, doi: $10.1108 / 17410390510609572$.

[11] P. D. Deshmukh and G. T. Thampi, "Empirical analysis of factors influencing ERP implementation in Indian SMEs," Proc. 2014 Int. Conf. Adv. Comput. Commun. Informatics, ICACCI 2014, pp. 2058-2062, 2014, doi: 1109/ICACCI.2014.6968625.

[12] C. Doom, K. Milis, S. Poelmans, and E. Bloemen, "Critical success factors for ERP implementations in Belgian SMEs," J. Enterp. Inf. Manag., vol. 23, no. 3, pp. 378-406, 2010, doi: 10.1108/17410391011036120.

[13] S. Gupta, S. C. Misra, N. Kock, and D. Roubaud, "Organizational, technological and extrinsic factors in the implementation of cloud ERP in SMEs," J. Organ. Chang. Manag., vol. 31, no. 1, pp. 83-102, 2018, doi: 10.1108/JOCM-06-2017-0230.

[14] S. W. Han, "ERP - Enterprise Resource Planning: A cost-based business case and implementation assessment," Hum. Factors Ergon. Manuf., vol. 14, no. 3, pp. 239-256, 2004, doi: 10.1002/hfm.10066.

[15] E. Hustad and D. H. Olsen, "Critical Issues Across the ERP Life Cycle in Small-andMedium- Sized Enterprises: Experiences from a Multiple Case Study," Procedia Technol., vol. 9, no. 2212, pp. 179-188, 2013, doi: 10.1016/j.protcy.2013.12.020.

[16] D. Aman, "Investigating factors affecting ERP selection in made-to-order SME sector," J. Manuf. Technol. Manag., vol. 19, no. 4, pp. 430-446, 2008, doi: $10.1108 / 17410380810869905$. 
[17] R. Jha, M. N. Hoda, A. K. Saini, B. N. Delhi, and N. Delhi, "Implementing Best Practices in ERP for Small \& Medium Enterprises 2 . How Successful ERP Selections are made," World, pp. 1-5, 2008.

[18] B. Johansson, A. Alajbegovic, V. Alexopoulo, and A. Desalermos, "Cloud ERP adoption opportunities and concerns: The role of organizational size," Proc. Annu. Hawaii Int. Conf. Syst. Sci., vol. 2015-March, pp. 4211-4219, 2015, doi: 10.1109/HICSS.2015.504.

[19] N. Karaarslan and E. Gundogar, "An application for modular capability-based ERP software selection using AHP method," Int. J. Adv. Manuf. Technol., vol. 42, no. 9-10, pp. 1025-1033, 2009, doi: 10.1007/s00170-008-1522-5.

[20] H. S. Kilic, S. Zaim, and D. Delen, "Selecting 'the best' ERP system for SMEs using a combination of ANP and PROMETHEE methods," Expert Syst. Appl., vol. 42, no. 5, pp. 2343-2352, 2015, doi: 10.1016/j.eswa.2014.10.034.

[21] S. Laukkanen, S. Sarpola, and P. Hallikainen, "ERP system adoption - Does the size matter?," Proc. Annu. Hawaii Int. Conf. Syst. Sci., vol. 00, no. C, p. 226, 2005, doi: 10.1109/hicss.2005.245.

[22] S. Gupta, and C. Misra, "Compliance, network, security and the people related factors in cloud ERP implementation,” Int. J. Commun. Syst., vol. 23, no. 5, pp. 633-652, 2010, doi: $10.1002 /$ dac.

[23] J. Lewandowski, A. O. Salako, and A. Garcia-Perez, "SaaS enterprise resource planning systems: Challenges of their adoption in SMEs," Proc. - 2013 IEEE 10th Int. Conf. E-bus. Eng. ICEBE 2013, pp. 56-61, 2013, doi: 10.1109/ICEBE.2013.9.

[24] H. Liang and Y. Xue, "Coping with ERP-related contextual issues in SMEs: A vendor's perspective," J. Strateg. Inf. Syst., vol. 13, no. 4 SPEC. ISS., pp. 399-415, 2004, doi: 10.1016/j.jsis.2004.11.006.

[25] B. Light and E. Wagner, "Integration in ERP environments: Rhetoric, realities and organisational possibilities," New Technol. Work Employ., vol. 21, no. 3, pp. 215-228, 2006, doi: 10.1111/j.1468-005X.2006.00176.x.

[26] N. Limantara and F. Jingga, "Open Source ERP: ODOO Implementation at Micro Small Medium Enterprises," Ieee, vol. November, no. November, pp. 340-344, 2017, [Online]. Available: https://ieeexplore.ieee.org/stamp/stamp.jsp?tp=\&arnumber=8273562.

[27] F. Meng, N. Wang, and Y. Xu, "Triangular Fuzzy Neutrosophic Preference Relations and Their Application in Enterprise Resource Planning Software Selection," Cognit. Comput., vol. 12, no. 1, pp. 261-295, 2020, doi: 10.1007/s12559-19-09640-4.

[28] M. Newman and Y. Zhao, "The process of enterprise resource planning implementation and business process re-engineering: Tales from two Chinese small and medium-sized enterprises," Inf. Syst. J., vol. 18, no. 4, pp. 405-426, 2008, doi: 10.1111/j.13652575.2008.00305.x.

[29] P. Nikolaos, G. Sotiris, D. Harris, and V. Nikolaos, "An application of multicriteria analysis for ERP software selection in a Greek industrial company," Oper. Res., vol. 5, no. 3, pp. 435-458, 2005, doi: 10.1007/bf02941130. 
[30] L. Raymond and S. Uwizeyemungu, "A profile of ERP adoption in manufacturing SMEs," J. Enterp. Inf. Manag., vol. 20, no. 4, pp. 487-502, 2007, doi: 10.1108/17410390710772731.

[31] D. Reuther and G. Chattopadhyay, "Critical factors for enterprise resources planning system selection and implementation projects within small to medium enterprises," IEEE Int. Eng. Manag. Conf., vol. 2, pp. 851-855, 2004, doi: 10.1109/iemc.2004.1407502.

[32] P. Ruivo, B. Johansson, T. Oliveira, and M. Neto, "Commercial ERP Systems and User Productivity: A Study Across European SMEs," Procedia Technol., vol. 9, pp. 84-93, 2013, doi: 10.1016/j.protcy.2013.12.009.

[33] P. Ruivo, B. Johansson, T. Oliveira, and M. Neto, "Determinants that Influence ERP Use and Value: Cross-Country Evidence on Scandinavian and Iberian SMEs," Procedia Technol., vol. 5, pp. 354-362, 2012, doi: 10.1016/j.protcy.2012.09.039.

[34] P. Ruivo, T. Oliveira, and M. Neto, "Using resource-based view theory to assess the value of ERP commercial-packages in SMEs," Comput. Ind., vol. 73, pp. 105-116, 2015, doi: 10.1016/j.compind.2015.06.001.

[35] I. Saini, A. Khanna, and S. K. Peddoju, "Cloud and traditional ERP systems in small and medium enterprises," Proc. 2014 Int. Conf. Inf. Syst. Comput. Networks, ISCON 2014, pp. 138-141, 2014, doi: 10.1109/ICISCON.2014.6965234.

[36] S. Saini, S. Nigam, and S. C. Misra, "Success factors for implementing ERP in SMEs in India: A conceptual model,” ICIME 2010 - 2010 2nd IEEE Int. Conf. Inf. Manag. Eng., vol. 4, pp. 165-169, 2010, doi: 10.1109/ICIME.2010.5477515.

[37] S. Saini, S. Nigam, and S. C. Misra, "Identifying success factors for implementation of ERP at Indian SMEs: A comparative study with Indian large organizations and the global trend," J. Model. Manag., vol. 8, no. 1, pp. 103-122, 2013, oi: 10.1108/17465661311312003.

[38] R. Seethamraju, "Adoption of Software as a Service (SaaS) Enterprise Resource Planning (ERP) Systems in Small and Medium Sized Enterprises (SMEs)," Inf. Syst. Front., vol. 17, no. 3, pp. 475-492, 2015, doi: 10.1007/s10796-014-9506-5.

[39] S. S. Shahawai and R. Idrus, "Malaysian SMEs perspective on factors affecting ERP system adoption," Proc. - AMS 2011 Asia Model. Symp. 2011 - 5th Asia Int. Conf. Math. Model. Comput. Simul., pp. 109-113, 2011, doi: 10.1109/AMS.2011.30.

[40] S. S. Shahawai and R. Idrus, "Research methodology for assessing malaysian SMEs perspective on ERP," Proc. - 2009 3rd Asia Int. Conf. Model. Simulation, AMS 2009, pp. 407-412, 2009, doi: 10.1109/AMS.2009.122.

[41] J. Siswanto and A. Maulida, "Validated ERP modules requirement for micro, small and medium enterprise fashion industry," 2016 Int. Conf. Inf. Technol. Syst. Innov. ICITSI 2016 - Proc., 2017, doi: 10.1109/ICITSI.2016.7858243.

[42] J. Siswanto and A. Maulida, "ERP module requirements for micro, small and medium enterprise fashion industry in Bandung," 2014 Int. Conf. Inf. Technol. Syst. Innov. ICITSI 2014 - Proc., no. November, pp. 183-188, 2014, doi: 10.1109/ICITSI.2014.7048261.

[43] D. Sledgianowski, M. H. A. Tafti, and J. Kierstead, "SME ERP system sourcing strategies: A case study," Ind. Manag. Data Syst., vol. 108, no. 4, pp. 421-436, 2008, doi: $10.1108 / 02635570810868317$. 
[44] S. Tasnawijitwong and T. Samanchuen, "Open source ERP selection for small and medium enterprises by using analytic hierarchy process," Proc. 2018 5th Int. Conf. Bus. Ind. Res. Smart Technol. Next Gener. Information, Eng. Bus. Soc. Sci. ICBIR 2018, pp. 382-386, 2018, doi: 10.1109/ICBIR.2018.8391226.

[45] A. Terminanto and A. N. Hidayanto, "Identifying characteristics and configurations in open source ERP in accounting using ASAP: A case study on SME," Proc. - 2017 Int. Conf. Soft Comput. Intell. Syst. Inf. Technol. Build. Intell. Through IOT Big Data, ICSIIT 2017, vol. 2018-Janua, pp. 227-232, 2017, doi: 10.1109/ICSIIT.2017.47.

[46] R. Valanarasu and A. Christy, "Enhancement of enterprise resource planning system by analysing feasibility and critical factors," Int. J. Adv. Intell. Paradig., vol. 17, no. 1-2, pp. 3-16, 2020, doi: 10.1504/IJAIP.2020.108756.

[47] J. A. A. van Beijsterveld and W. J. H. van Groenendaal, "Solving misfits in ERP implementations by SMEs," Inf. Syst. J., vol. 26, no. 4, pp. 369-393, 2016, doi: 10.1111/isj.12090.

[48] L. X. X. Xia, W. F. Yu, R. Lim, and L. E. Hock, "A methodology for successful implementation of ERP in smaller companies," Proc. 2010 IEEE Int. Conf. Serv. Oper. Logist. Informatics, SOLI 2010, pp. 380-385, 2010, doi: 10.1109/SOLI.2010.5551547.

[49] O. Zach and B. E. Munkvold, "Identifying reasons for ERP system customization in SMEs: A multiple case study," J. Enterp. Inf. Manag., vol. 25, no. 5, pp. 462-478, 2012, doi: $10.1108 / 17410391211265142$.

[50] M. Ziaee, M. Fathian, and S. J. Sadjadi, "A modular approach to ERP system selection: A case study," Inf. Manag. Comput. Secur., vol. 14, no. 5, pp. 485-495, 2006, doi: 10.1108/09685220610717772.

[51] B. Molnár, G. Szabó, and A. Benczúr, "Selection Process of ERP Systems," Bus. Syst. Res., vol. 4, no. 1, 2013, doi: 10.2478/bsrj-2013-0004. 